\title{
Exploring the Drivers of Intention to Use Interactive Whiteboards among Malaysia University Students: Does Technology Self-Efficacy Matter?
}

\author{
https://doi.org/10.3991/ijet.v15i01.11497 \\ Kung-Teck Wong $\left.{ }^{(}\right)$, Mazura @ Mastura Binti Muhammad, \\ Norazilawati Binti Abdullah \\ Sultan Idris Education University, Perak, Malaysia \\ thomas afpm.upsi.edu.my
}

\begin{abstract}
In Malaysia, its educational system has continually undergone a series of processes and transformations, especially in its curricula and delivery systems. Indeed, such educational reforms were influenced by the latest advancements in educational technology, where changes introduced were meant to equip students with the 21 st-century skills as well as to help students face the impending global challenges with greater confidence. Lately, many works of literature have confirmed the advantages of integrating Interactive whiteboard (IWB) in teaching and learning. The aim of this study was to develop a model which demonstrates the variables that affect student teachers' intentions and which also explain their interactions. The proposed IWB intention to use research model is based on prominent educational technology acceptance theories and models. Technology self-efficacy (TSE), Intention to Use (IU), Performance Expectancy (PE), Social Influence (SI) and Effort Expectancy (EE) variables were selected to build a model for this study. Structural Equation Modelling (SEM) was used for this study to identify the predictors and the model fit. The proposed model has accounted for $47.6 \%$ of the variance in the intention to use IWB.
\end{abstract}

Keywords - Technology self-efficacy, Interactive whiteboard, Student-teacher

\section{Introduction}

The emergence of Interactive Whiteboard (IWB) as a new pedagogical practice has become an interesting topic in the transformation of educational technology. The student-centered pedagogy practices have repeatedly been proven to be effective than conventional teaching and learning practices [1-2]. There is abundant studies have proven that the use of IWB is able to improve and create interesting classrooms environment [3].

IWB is a whiteboard that is connected to an overhead projector via a computer. With IWB, collaborative interaction among groups of students can be done simultaneously with the multi-touch and multi-user interactive board [4-6]. Advocates of the nation argue that IWB plays a crucial role in encouraging students' participation and 
improve their motivation to learn [5]. Furthermore, IWB provides better studentcentered collaborative environments [1-2] if compare to the conventional teaching approaches (7-9].

Besides that, the advantages of integrating IWB in classrooms have a significant impact on a number of subjects such as science, mathematics, history, early learning, special education, language and literacy and etc. [10-12]. The use of IWB in teaching and learning is very common in Denmark (50\%), Netherlands (47\%) and Australia (13). Furthermore, from the literature, it highlighted the importance of facilitating conditions [14], ease of use [14-15], performance expectancy [15], self-efficacy [16] and social influence [17] in affecting the use of IWB in teaching and learning.

However, most of those studies were carried out in the west and having that, it has its limitations especially apply in developing countries. Furthermore, some of the studies focused on non-educational contexts [3, 18-19] and having that its factors influencing the integration of IWB in the classroom settings might be different from previous studies. In this study, IWB is applied in classroom environments and for educational purposes.

Based on the above research statement of the problem and its different settings and contexts, this study was to understand the predictors especially self-efficacy factors towards the intended use of the IWB model among student teachers in Malaysia setting. The theories and models of educational technology acceptance have been employed for developing the IWB intention to use model. SI, PE, EE, TSE, and IU were used to develop the IWB intention to use the model in this study.

\section{The Study}

In the process of understanding the predictors for the use of IWB among student teachers, systematic reviews have been carried out. Evidence from literature reviews, the Theory of Planned Behaviour (TPB) [20], the Social Cognitive Theory (SCT) [21], the Technology Acceptance Model (TAM) [19, 28, 30], the Theory of Acceptance and Use of Technology (UTAUT) [15], the Theory of Reasoned Action (TRA) [23], and the Technology Acceptance Model 2 (TAM2) [15], have been commonly used for testing and understanding the acceptance and use of technology integration in teaching and learning. The TRA, TAM2, TPB, SCT, and UTAUT are the main models which consisted of predictors that have significant predictors predict technology acceptance among educators. Alongside, these models successfully explain an average of $38 \%$ or more of the variances in different settings of use and acceptance of technologies [3, 13-14].

Based on the theories and models, the current study has proposed five predictive factors. These are SI, PE, EE, TSE, and IU. Based on the previous studies on the acceptance of technologies based educational tools, the researchers predicted that those predictive variables could explain on the predictors of IWB use. Table 1 shows the causal links of the predictors (exogenous constructs) of Intention to Use of IWB (endogenous construct). 
Based on the theories and model, the following hypothesis was generated and as reflected the Figure 1.

- H1: Technology self-efficacy (TSE) will statistically contribute to student teachers' performance expectancy (PE) in the use of interactive whiteboards.

- H2: Technology self-efficacy (TSE) will statistically contribute to student teachers' intention to use (IU) in the use of interactive whiteboards.

- H3: Technology self-efficacy (TSE) will statistically contribute to student teachers' effect expectancy (EE) in the use of interactive whiteboards.

- H4: Technology self-efficacy (TSE) will statistically contribute to student teachers' social influence (SI) in the use of interactive whiteboards.

- H5: Performance expectancy (PE) will statistically contribute to student teachers' intention to use (IU) in the use of interactive whiteboards.

- H6: Effort expectancy (EE) will statistically contribute to student teachers' performance expectancy (PE) in the use of interactive whiteboards.

- H7: Effort expectancy (EE) will statistically contribute to student teachers' intention to use (IU) in the use of interactive whiteboards.

- H8: Social influence (SI) will statistically contribute to student teachers' intention to use (IU) in the use of interactive whiteboards.

Table 1. The causal links of the predictors (exogenous constructs) of Intention to use of IWB (endogenous construct)

\begin{tabular}{|l|l|l|}
\hline \multicolumn{1}{|c|}{ Variables } & \multicolumn{1}{|c|}{ Definition of Terms } & Links of the variables \\
\hline Technology Self-efficacy (TSE) & $\begin{array}{l}\text { The level of users believe of their capabilities to } \\
\text { use the IWB, and their individual beliefs of } \\
\text { integrating IWB can improve learners academic } \\
\text { achievements. }\end{array}$ & $\begin{array}{l}\text { SE } \rightarrow \text { PE } \\
\mathrm{SE} \rightarrow \mathrm{EE} \\
\mathrm{SE} \rightarrow \mathrm{SI}\end{array}$ \\
\hline Performance Expectancy (PE) & $\begin{array}{l}\text { The users believe that IWB could assist them in } \\
\text { their job pathway. }\end{array}$ & PE $\rightarrow \mathrm{IU}$ \\
\hline Effort Expectancy (EE) & $\begin{array}{l}\text { The users believe that IWB is user-friendly and } \\
\text { manageable. }\end{array}$ & $\begin{array}{l}\mathrm{EE} \rightarrow \mathrm{IU} \\
\mathrm{EE} \rightarrow \mathrm{PE}\end{array}$ \\
\hline Social Influence (SI) & $\begin{array}{l}\text { The users will change their belief and attitude } \\
\text { towards the use of IWB for teaching and learning. }\end{array}$ & SI $\rightarrow \mathrm{IU}$ \\
\hline
\end{tabular}

\section{$3 \quad$ Methodology}

\subsection{Research design}

In this study, a self-report questionnaire was employed as an instrument for data collection. The questionnaire containing items connected to individual demographic information and scales examining the variables (exogenous and endogenous) in the proposed model (PE, IU, TSE, SI, EE). Figure 1 shows the proposed IWB intention to use research model for the study. 


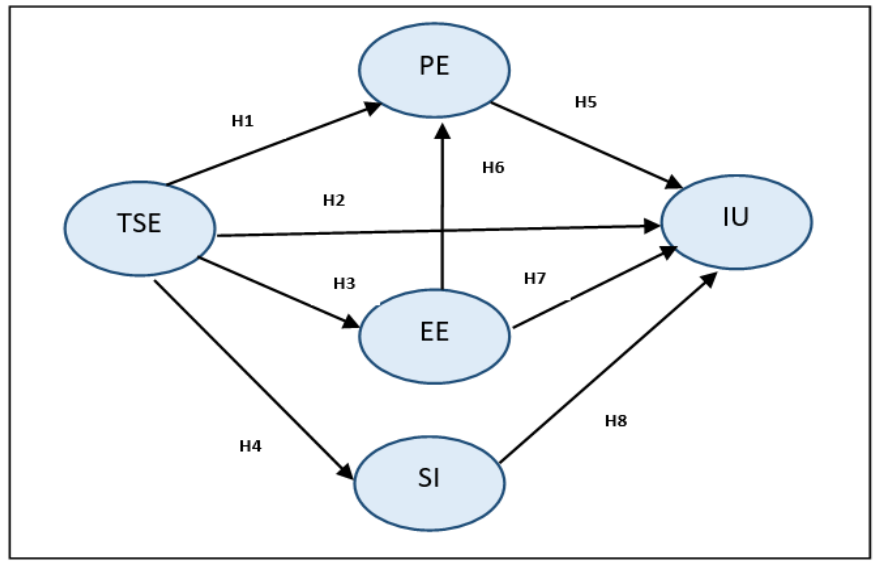

Fig. 1. Proposed research model

Methodologically, this study has employed structural equation modeling (SEM) to understand the intention to integrate interactive whiteboards among Malaysia university students. SEM is commonly used for predicting and understanding latent variables against the observed data collected from the study, especially in an educational setting [3]. With the SEM, the findings can explain the total variance with regard to the endogenous variable. Thus, AMOS 22.0 statistics software program was used in this study. Noticeably, in SEM, the results are more precise and higher reliability measurements as it involves random errors in the observed variables [13-14].

\section{Data Collections and The Participants}

Participants of this study consisted of student teachers enrolled in Malaysia universities or institutions at the beginning of the academic year 2017/2018. The participants have experienced with IWBs for more than 2 years regardless of the type of interactive whiteboard. All the participants have explained regards to the aims of the study and have been informed of their rights in withdrawing from completing the survey question whenever they preferred. No course credits will be given for this participation and it was anonymous. A total of 202 student teachers involved in the study. Among them, 123 (60.4\%) were undergraduate candidates, 79 (39.1\%) were diploma candidates, making a response rate of $34.6 \%$. Of these participants, 177 (84.2\%) were female. Imbalance of gender depiction as the less male pre-services teachers in the Malaysia universities and education institutions in Malaysia context. Approximately, it took $25 \mathrm{~min}$ to answer the survey questions.

\subsection{Development of the instruments}

The questionnaire was created for this study. A total of 19 items was created to understand the intentional use of IWB as media of instruction in the classrooms among 
pre-service teachers in Malaysia universities and institutions. The items were; 4 items for Perceived usefulness (PU); 4 items for Performance Expectancy (PE); 4 items for Technology self-efficacy (TSE); 4 items for Social Influence (SI); 3 items for Intention to Use (IU). Student-teachers responded to a four-point Likert scale ranging from strongly agree (4) to strongly disagree (1). All items presented in Malay and English language. All the items in the self-reported survey were modified from published sources. Indeed, the psychometric quality of the items has high reliability and validity, especially on the factor loadings.

\section{$5 \quad$ Data Analysis and Findings}

\subsection{The validities and reliabilities of the instrument}

An investigation of the validities and reliabilities of the self-report instrument was conducted to certify the validity and reliability of each item. In this regards, an exploratory factor analysis (EFA) and a confirmatory factor analysis (CFA) were being carried out before the analysis of its causal-relationships of the exogenous and endogenous variables.

\subsection{Exploratory factor analysis (EFA)}

In this study, EFA is a statistical method used to describe variability among observed, correlated variables on the dataset and its loadings factors structure.

The findings of this study showed that all the proposed items were loaded above .50 and in the range from .50 to .98 . If the factor loading is more than .50 , is considered a good item [3].

Appendix 1 shows the 5 factors loading structure in the IWB intention to use model and the predictors successfully explained $46.6 \%$ of the total variance of pre-service teachers' intention to integrate the new pedagogical of IWB as the media of instruction in the classrooms.

Alongside the results of the analysis have indicated that the Kaiser-Meyer-Olkin (KMO) (.881) and with Bartlett's test $(\mathrm{p}<.001)$. Based on the results, the constructs were fulfilled the minimum criteria of analysis.

\subsection{Confirmatory factor analysis (CFA)}

In the study, confirmatory factor analysis was carried out to understand the stability of the factor structure and to identify the unobserved variables signified by the observed indicators. Based on the results as shown in Table 2, all parameter estimates from the suggested items used for predictors the integration of IWB in teaching and learning were significant $(\mathrm{p}<.05)$. In addition, from the outputs of CFA, all parameter estimates were greater than 1.96 .

According to Teo and Lee, 2010, if the regression weights (standardized values) were above .50 , it considered as appropriated and can be accepted for structural equa- 
tion analysis (SEM). Based on the findings of the study, all the standardized values of the regression weights were above .50 , ranging from .63 to .92 . Thus, it has proven it validities of the suggested items for the model.

Additionally, to assess the model fit, the study has employed the five absolute-fit indices. Table 3 shows the model fits indices and its minimum thresholds of each criterion. Absolute-fit indices are important to indicate whether or not the proposed model reaches the minimum requirements based on the observed data.

The results from the confirmatory factor analysis indicated that GFI and CFI have achieved the minimum thresholds of the required values (more than 0.90). Having that, it can be concluded that the model showed a good model.

The table below shows the fit indices of the measurement model proposed for the study and its level of acceptable fit. Based on the findings, all indices have reached the minimum thresholds of model-fit.

Table 2. Measurement model results

\begin{tabular}{|c|c|c|c|c|}
\hline Latent Variable & Item & SE & $\begin{array}{c}\text { Average Variance } \\
\text { Extracted }^{\mathrm{a}}\end{array}$ & $\begin{array}{c}\text { Composite Reliability }^{b} \\
(\geq .50) \\
\end{array}$ \\
\hline \multirow{4}{*}{ PU } & PU1 & 0.87 & \multirow{4}{*}{0.84} & \multirow{4}{*}{.90} \\
\hline & PU2 & 0.85 & & \\
\hline & PU3 & 0.81 & & \\
\hline & PU4 & 0.84 & & \\
\hline \multirow{4}{*}{ PE } & PE 1 & 0.67 & \multirow{4}{*}{0.76} & \multirow{4}{*}{.85} \\
\hline & PE 2 & 0.90 & & \\
\hline & PE 3 & 0.76 & & \\
\hline & PE 4 & 0.70 & & \\
\hline \multirow{4}{*}{ SI } & SI1 & 0.73 & \multirow{4}{*}{0.77} & \multirow{4}{*}{.84} \\
\hline & SI2 & 0.85 & & \\
\hline & SI3 & 0.80 & & \\
\hline & SI4 & 0.68 & & \\
\hline \multirow{4}{*}{ TSE } & TSE1 & 0.63 & \multirow{4}{*}{0.76} & \multirow{4}{*}{.85} \\
\hline & TSE2 & 0.89 & & \\
\hline & TSE3 & 0.82 & & \\
\hline & TSE4 & 0.75 & & \\
\hline \multirow{3}{*}{ IU } & IU 1 & 0.82 & \multirow{3}{*}{0.83} & \multirow{3}{*}{.82} \\
\hline & IU 2 & 0.92 & & \\
\hline & IU 3 & 0.76 & & \\
\hline
\end{tabular}

Table 3. The measurement model of Goodness of fit Indices

\begin{tabular}{|l|c|c|}
\hline \multicolumn{1}{|c|}{ Fit indices } & Values & Criteria $^{\text {a }}$ \\
\hline$\chi^{2}$ Statistic & $220.953^{*}$ & Significant / insignificant $^{*}$ \\
\hline$\chi^{2} / d f$ & 1.567 & $<3.0$ \\
\hline TLI. & .955 & $\geq .90$ \\
\hline CFI. & .963 & $\geq .90$ \\
\hline GFI. & .900 & $\geq .90$ \\
\hline RMSEA. & .053 & $<.08$ \\
\hline
\end{tabular}


To look in details of the item's properties of the survey question, Cronbach's $\alpha$ and discriminant validity have been carried out. The findings from the analysis also indicated that all the proposed items achieve minimum thresholds with value of Cronbach's $\alpha$ more than .60 (Table 2). Also, the results in Table 4 shows that discriminant validity was achieved its minimum requirement.

Table 4. The discriminant validity results

\begin{tabular}{|l|c|c|c|c|c|}
\hline & TSE & PE & PU & SI & IU \\
\hline TSE & $\mathbf{( 0 . 7 7 6 )}$ & & & & \\
\hline PE & 0.494 & $\mathbf{( 0 . 7 6 5 )}$ & & & \\
\hline PU & 0.255 & 0.341 & $\mathbf{( 0 . 8 4 4 )}$ & & \\
\hline SI & 0.361 & 0.256 & 0.256 & $\mathbf{( 0 . 7 6 8 )}$ & \\
\hline IU & 0.427 & 0.402 & 0.625 & 0.229 & $\mathbf{( 0 . 8 3 5 )}$ \\
\hline
\end{tabular}

Taking intention to use (IU) interactive whiteboards as an endogenous variable, and Perceived usefulness (PU), Performance Expectancy (PE), Technology selfefficacy (TSE) and Social Influence (SI) as exogenous variables, thus the path by path of the suggested model was carried out and tested.

The five absolute-fit indices for testing the model fit were used in the study. These are Rmsea, Cfi, Tls, Gfi and its chi-square of df. From the analysis of the study using AMOS-SEM, all the suggested research model has achieved its minimum threshold indexes $\left(\chi^{2}=216.667, \mathrm{p}<0.01 ; \chi 2 / \mathrm{df}=1.515 ; \mathrm{Gfi}=.902 ; \mathrm{Cfi}=.966 ; \mathrm{Tli}=.959\right.$ and Rmsea $=0.05)$.

From the results, the proposed path model in this study has exceeded the minimum threshold value of good fit. Except for the $\chi 2$, all indices were above the suggested thresholds for a satisfactory model fit Figure 1 shows the standardized path coefficients for the hypothesized model. In short, the findings indicated that out of eight (8) hypotheses, five (5) hypotheses were supported in this study.

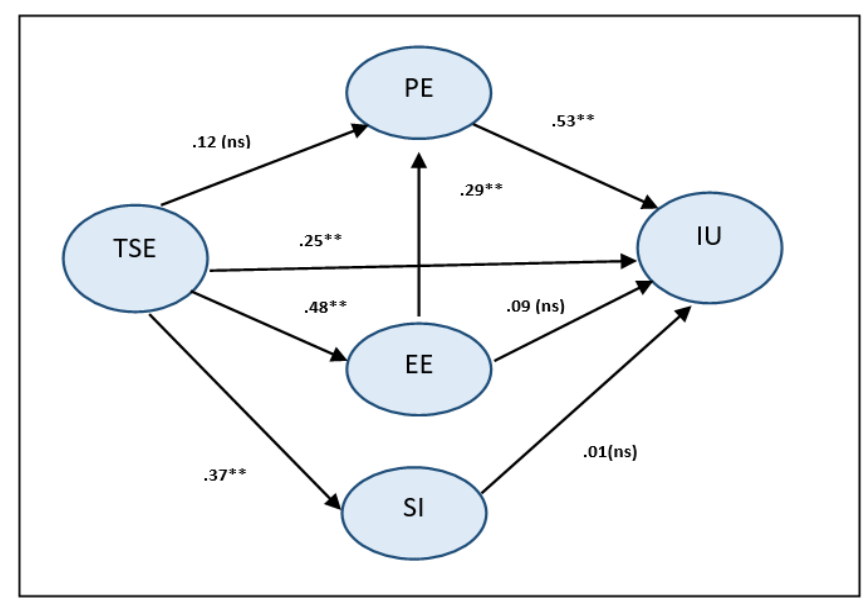

Fig. 2. Standardised path coefficients 
ns $=$ Not Significant

The exogenous variable, technology self-efficacy, has a strong relationship on social influence $(\beta=.37, \mathrm{p}<.00)$ and effort expectancy $(\beta=.48, \mathrm{p}<.00)$. Technology selfefficacy $(\beta=.25, \mathrm{p}<.00)$ and performance expectancy $(\beta=.53, \mathrm{p}<.00)$ were indicated to have a significant contribution to the intention to integrate interactive whiteboards among student teachers.

Performance expectancy $(\beta=.29, \mathrm{p}<.00)$ also to be significant towards effort expectancy. Having that, all hypotheses were accepted in this study, except H1, H7, and H8. Furthermore, technology self-efficacy accounted for $36.7 \%(\mathrm{R} 2=0.367)$ of the combination of variance in effort expectancy and social influence in the use of interactive whiteboards among student teachers. Overall, the intention to use (IU) was showed to be good determined by technology self-efficacy, performance expectancy, and effort expectancy (indirectly) $\left(\mathrm{R}^{2}=.48\right)$. Based on this finding, exogenous variables (TSE, $\mathrm{PE}, \mathrm{EE}, \mathrm{SI})$ in the model successfully contributed to $47.6 \%$ of the variance of intention to use (IU) of IWB among student teachers in Malaysia

\section{Direct and Indirect Effect on The Endogenous Variable}

The study also identifies the direct effects, indirect effects and total effects (standardized effects) of the exogenous factors and endogenous factors towards the integration of IWB in teaching and learning. Based on Table 4, the sum of indirect effects and direct effects were contributed to the total effects of the given predictors. The direct effect is the effect coefficient from one predictor to another predictor in the structural model.

Table 5 shows Performance Expectancy (PE) was the most dominant predictors towards IU (total effect $=.53$ ). Technology self-efficacy $(0.43)$, effort expectancy $(0.25)$ and social influence $(0.02)$ were the subsequence predictors for IU.

Additionally, technology self-efficacy indicated as a good predictor for both indirect effects and direct effects on IU variables in the research model. Thus, it concluded that technology self-efficacy (TSE) has significantly influencing whether or not student teachers interested to integrate and use IWB for their teaching and learning in the classrooms in Malaysia setting.

Table 5. Total Effects, Indirect Effects, and Direct Effects Results

\begin{tabular}{|c|c|c|c|c|c|}
\hline \multirow{2}{*}{ Outcome } & \multirow{2}{*}{ Predictors } & \multicolumn{4}{|c|}{ Standardized estimates } \\
\hline & & $R^{2}$ & Indirect & Direct & Total \\
\hline SI & TSE & .136 & - & .368 & .368 \\
\hline \multirow[t]{2}{*}{$\mathrm{PE}$} & TSE & \multirow{2}{*}{.134} & .139 & .123 & .262 \\
\hline & SI & & - & .290 & .290 \\
\hline EE & TSE & .231 & - & .480 & .480 \\
\hline \multirow{4}{*}{ IU } & $\mathrm{PE}$ & \multirow{4}{*}{.476} & - & .528 & .528 \\
\hline & EE & & .153 & .096 & .249 \\
\hline & SI & & - & .015 & .015 \\
\hline & TSE & & .179 & .252 & .431 \\
\hline
\end{tabular}




\section{Discussion}

The purposes of this study were to understand the key predictors' intention to use interactive whiteboards among Malaysia university students. The study is very important as technology has become important in the education setting [29]. This study empirically exploring a step further to identify the importance of self-efficacy in influencing SI, PE, EE and IU variables. Overall the results of the study served many vital implications for the policies and practices of integration of technologies especially in the integration of interactive whiteboards for pre-service teachers in universities and the teaching institutions in Malaysia. Based on the findings, the research model explained $47.6 \%$ of the variance of IU for IWB among pre-service teachers in Malaysia setting. Based on the indices of goodness-of-fit from the structure model, the measurement model for this study represented by the data analyzed from the study and predictors on pre-service teachers' intention to use interactive whiteboards.

The results are congruent with the results of earlier studies on effort expectancy on educational technologies, social influence from colleagues or peers and intention to use new technologies in teaching and learning which found the good influential effect of technology self-efficacy on technology use [3, 20, 22, 25 - 27].

Based on the sizes of the indirect, directs or total effects of the outcomes, the key determinant of intention to integrate interactive whiteboard for teaching and learning by student-teachers was performance expectancy, followed by technology selfefficacy, effort expectancy, and social influence. Based on the findings, performance expectancy was found to be the highest variance towards intention to use of IWB $(\beta=.528, \mathrm{p}<.05)$. These findings are coherent with the previous studies [21-23]. On this basis, it reflects that pre-service educators will integrate their teaching with IWB when they believe that by using interactive whiteboards when to perceive a continuing advantage of it. The study has found a robust correlation between performance expectancy and intention to use (IU) for interactive whiteboard among pre-service teachers. This indicated that determinations to prepare per-services educators in use of interactive whiteboards successfully should synchronize with its pedagogical benefits. Overalls, with regard to technology self-efficacy, the findings showed that technology selfefficacy had significant positive effects on other predictors such as effort expectancy (EE), social influence (SI) and intention to use (IU) the interactive whiteboards in the process of educating among pre-service teachers.

\section{$8 \quad$ Limitation and Recommendations Future Research}

Some primary limitations mirror the need for further investigations. First, as selfreporting items were used in this study, thus suggesting the possibility of bias in the outputs of the study due to participants may have heterogeneous of IWBs knowledge and skills, various types of interactive whiteboard in schools. On this basis, it is reasonable to expect that numerical estimation could occur in this study. However, the researchers have made afford to minimize them. Having this, future study should be replicated by using a larger sample with same type of interactive whiteboard tools and 
control the level of knowledge and skills among student teachers. Second, the participants of the study involved only participants from student teachers enrolled in Malaysia universities or institutions at the beginning of the academic year 2017/2018 and having this the results may not adequately reflect the perceptions of the general student teachers as a whole.

\section{Acknowledgement}

Great appreciation is communicated to Sultan Idris Education University (UPSI), Perak, Malaysia for the research grant (2018-0030-107-01) and the Ministry of Education (MOE) Malaysia for the support of this research.

\section{References}

[1] Vasilescu, Cezar \& Codreanu, Aura. (2013). E-Learning Behaviors and Their Impact on Andragogy. 10.13140/Rg.2.1.4223.7289.

[2] Galustyan O.V., Borovikova Y.V., Polivaeva N.P., Kodirov B.R., Zhirkova G.P. (2019). E-learning within the Field of Andragogy. International Journal of Emerging Technologies in Learning, 14 (9), 148-156. https://doi.org/10.3991/ijet.v14i09.10020

[3] Wong, K.T, Teo, T., \& Goh, P.S.C. (2014). Development of the Interactive Whiteboard Acceptance Scale (IWBAS): An Initial Study. Educational Technology \& Society, 17(4), 268-277. https://doi.org/10.1037/t59864-000

[4] Wong, K. T., Teo, T., \& Pauline, S.C.G. (2015). Understanding and intention to use interactive whiteboard: Model development and testing. Interactive Learning Environments. 23(6), 731-747. https://doi.org/10.1080/10494820.2013.806932

[5] Ma, Yue. (2019). Design and Implementation of a College Teacher Training System Based on Client-Server Structure. International Journal of Emerging Technologies in Learning (iJET). 14. 121. https://doi.org/10.3991/ijet.v14i12.10716

[6] Zhang, Yuan \& Zuo, Lu. (2019). College English Teaching Status and Individualized Teaching Design in The Context of Mobile Learning. International Journal of Emerging Technologies in Learning (iJET). 14. 85. https://doi.org/10.3991/ijet.v14i12. $\underline{10704}$

[7] Liu, Feng-juan. (2018). A Quantitative Evaluation Model of Interactive Whiteboard Classroom Based on K-Means Algorithm. International Journal of Emerging Technologies in Learning (iJET). 13. 89. https://doi.org/10.3991/ijet.v13i11.9603

[8] Stroud, Rena \& Drayton, Brian \& Hobbs, Kathryn \& Falk, Joni. (2014). Interactive Whiteboard Use in High-Tech Science Classrooms: Patterns of Integration. International Journal of Emerging Technologies in Learning (iJET). 9. 41.https://doi.org/10.3991/ ijet.v9i9.4141

[9] Daher, Wajeeh \& Abu Hussain, Jamal \& Alfahel, Eisa. (2012). Teachers' Perceptions of Interactive Boards for Teaching and Learning in Public and Private High Schools in the Arab Education System in Israel. International Journal of Emerging Technologies in Learning (iJET). 7 https://doi.org/10.3991/ijet.v7i1.1775

[10] Goodwin, K. (2008). The impact of interactive multimedia on kindergarten students' representations of fractions. Educational Research, 18(2), 103-117. 
[11] Bonk, C.J., \& Cunningham, D.J. (1998). Searching for learner-centered, constructivist, and sociocultural components of collaborative educational learning tools. In Bonk, C.J., \& Kim, K.S. (Eds.), Electronic collaborators: Learner-centered technologies for literacy, apprenticeship, and discourse (25-50). New Jersey: Erlbaum.

[12] Shenton, A., \& Pagett, L. (2007). From 'bored' to the screen: The use of the interactive whiteboard for literacy in six primary classrooms in England. Literacy, 41(3), 129-136. https://doi.org/10.1111/j.1467-9345.2007.00475.x

[13] Türel, Y.K. (2011), An interactive whiteboard student survey: Development, validity and reliability, Computers \& Education, 57(4), 2441-2450.https://doi.org/10.1016/ j.compedu.2011.07.005

[14] Teo, T., \& Lee, C.B. (2010). Explaining the intention to use technology among student teachers: An application of the Theory of Planned Behaviour (TPB). Campus-Wide Information Systems, 27(2), 60-66. https://doi.org/10.1108/10650741011033035

[15] Venkatesh, V., \& Zhang, X. (2010). Unified theory of acceptance and use of technology: U.S. Vs. China. Journal of Global information Technology Management, 13(1), 5-24. https://doi.org/10.1080/1097198X.2010.10856507

[16] Ramayah, T., \& Lo, M. (2007). Impact of shared beliefs on PU and ease of use in the implementation of enterprise resource planning system. Management Research News, 30(6), 420-431. https://doi.org/10.1108/01409170710751917

[17] Zhou, T., Lu, Y., \& Wang, B. (2010). Integrating TTF and UTAUT to explain mobile banking user adoption. Computers in Human Behavior, 26(4), 760-767. https://doi.org/10.1016/j.chb.2010.01.013

[18] Wong, K.T., Hwang, G.J. \& Goh, P. S.C. \& Khadijah A. (2018). Effects of blended learning pedagogical practices on students' motivation and autonomy for the teaching of short stories in upper secondary English. Interactive Learning Environments. 114.https://doi.org/10.1080/10494820.2018.1542318

[19] Vatanartiran, S., \& Karadeniz, S. (2015). A needs analysis for technology integration plan: challenges and needs of teachers. Contemporary Educational Technology, 6(3), 206-220.

[20] Ajzen, I. (1991). The theory of planned behavior. Organizational Behavior and Human Decision Processes, 50(2), 179-211.https://doi.org/10.1016/0749-5978(91)90020-T

[21] Bandura, A. (1986). Social foundations of thought and action: A social cognitive theory Englewood Cliffs, NJ: Prentice Hall.

[22] Davis, F. D. (1989). Perceived usefulness, perceived ease of use, and user acceptance of information technology. MIS Quarterly, 13(3), 318-339. https://doi.org/10. $\underline{2307 / 249008}$

[23] Fishbein, M., \& Ajzen, I. (1975). Belief, attitude, intention and behavior: An introduction to theory and research. Reading, MA: Addison-Wesley.

[24] Insook Han, Won Sug Shin \& Yujung Ko (2017) The effect of student teaching experience and teacher beliefs on pre-service teachers' self-efficacy and intention to use technology in teaching, Teachers and Teaching, 23:7, 829-842,https://doi.org/10.1080/13540602. $\underline{2017.1322057}$

[25] Pei-Ying Chen \& Gwo-Jen Hwang (2019) An empirical examination of the effect of selfregulation and the Unified Theory of Acceptance and Use of Technology (UTAUT) factors on the online learning behavioural intention of college students, Asia Pacific Journal of Education, 39:1, 79-95 https://doi.org/10.1080/02188791.2019.1575184

[26] Matthew E. Harris, Robert J. Mills, Christopher Fawson \& Jeffrey J. Johnson (2018) Examining the Impact of Training in the Unified Theory of Acceptance and Use of Technology, Journal of Computer Information Systems, 58:3, 221-233, https://doi.org/10. $\underline{1080 / 08874417.2016 .1230725}$ 
[27] Bireswar Dutta, Mei-Hui Peng \& Shu-Lung Sun (2018) Modeling the adoption of personal health record (PHR) among individual: the effect of health-care technology self-efficacy and gender concern, Libyan Journal of Medicine, 13:1, https://doi.org/10.1080/ 19932820.2018 .1500349

[28] Papadakis, S. (2018). Evaluating pre-service teachers' acceptance of mobile devices with regards to their age and gender: a case study in Greece. International Journal of Mobile Learning and Organisation, 12(4), 336-352.https://doi.org/10.1504/IJMLO. 2018.095130

[29] Papadakis, St., Kalogiannakis, M., Sifaki, E., \& Vidakis, N. (2018). Evaluating Moodle use via Smart Mobile Phones. A case study in a Greek University, EAI (European Alliance for Innovation) Endorsed Transactions on Creative Technologies, 5(16), e1, 19.https://doi.org/10.4108/eai.10-4-2018.156382

[30] Kalogiannakis, M. \& Papadakis, S. (2019). Evaluating pre-service kindergarten teachers' intention to adopt and use tablets into teaching practice for natural sciences. Int. J. Mobile Learning and Organisation, 13(1), 113-127.https://doi.org/10.1504/IJMLO. 2019.096479

\section{Authors}

Kung-Teck Wong is an Assoc. Prof at Faculty of Education and Human Development, Sultan Idris Education University (UPSI), Malaysia. Prior to joining UPSI, he was a senior teacher in government schools. He completed his Ph.D. from University Malaysia Sabah and Post-Doctoral at the University of South Australia, Australia (UniSA). He has published extensively in local and international journals. He also serves as a reviewer of several local and ISI and SCOPUS indexed journals. In the past five years, he has secured many public and private research funding. Wong is interested in statistic studies and also the application of SPSS and AMOS -structural equation modeling in his writing articles and research. Email: thomas@fpm.upsi.edu.my

Mazura Mastura Muhammad is an Assoc. Prof at the Faculty of Languages and Communication, Sultan Idris Education University (UPSI), Malaysia. She pursued his $\mathrm{Ph}$.D. at the Lancaster University, United Kingdom. Mazura's areas of expertise are applied linguistics, corpus linguistics and policy research. In the past five years, she has secured various private and international research funding.

Norazilawati Abdullah is an Associate Professor, a presentable, self-motivated and confident lecturer with extensive knowledge on education. Possessing excellent counselling, listening and general communication skills, along with the ability to communicate to students in simple ways on matters regarding teaching and learning. Having exceptional multi-tasking and organizational skills, all of which are imperative when working closely with colleagues. With an already successful academic track record, now looking to accomplish further success in the area of teaching, supervising, research, publication and consultation with a progressive employer such us Sultan Idris Education University (UPSI).

Article submitted 2019-08-12. Resubmitted 2019-09-26. Final acceptance 2019-09-26. Final version published as submitted by the authors. 
Paper-Exploring the Drivers of Intention to Use Interactive Whiteboards among Malaysia University ...

\section{Appendix 1}

Factor loadings of the Exploratory Factor Analysis (EFA)

\begin{tabular}{|c|c|c|}
\hline Latent Variable & Item & SE \\
\hline \multirow{4}{*}{ EE } & PU1 & .803 \\
\hline & PU2 & .841 \\
\hline & PU3 & .740 \\
\hline & PU4 & .780 \\
\hline \multirow{4}{*}{ PE } & PE 1 & .857 \\
\hline & PE 2 & .836 \\
\hline & PE 3 & .831 \\
\hline & PE 4 & .847 \\
\hline \multirow{4}{*}{ SI } & SI1 & .795 \\
\hline & SI2 & .870 \\
\hline & $\mathrm{SI} 3$ & .819 \\
\hline & SI4 & .743 \\
\hline \multirow{4}{*}{ TSE } & TSE1 & .684 \\
\hline & TSE2 & .869 \\
\hline & TSE3 & .807 \\
\hline & TSE4 & .787 \\
\hline \multirow{3}{*}{ IU } & IU 1 & .717 \\
\hline & IU 2 & .835 \\
\hline & IU 3 & .774 \\
\hline
\end{tabular}

Extraction method: Principal Axis Factoring

Rotation method: Oblimin with Kaiser Normalization 